\title{
Comunicação freirática
}

\author{
José Camões
}

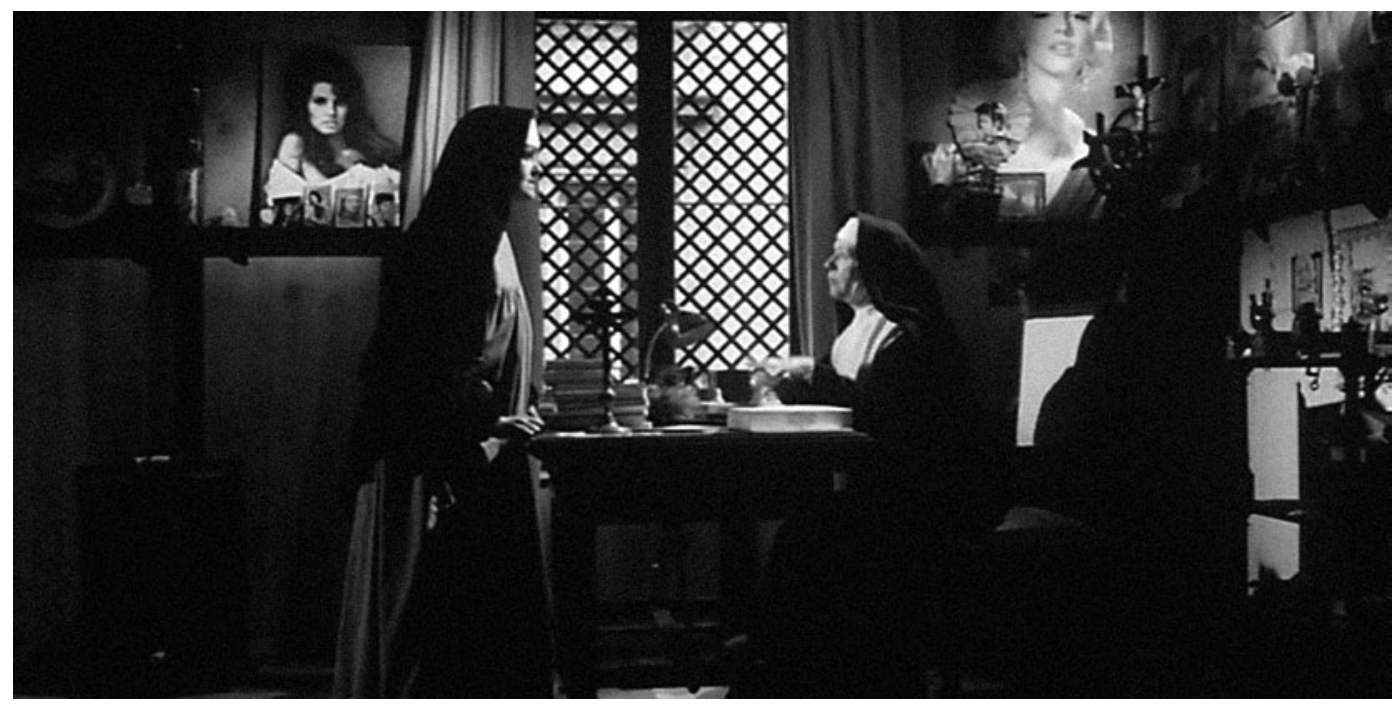

Ao longo dos séculos foi-se instalando na sociedade civil uma curiosidade, se não mesmo uma apetência, pelo conhecimento da vida claustral. Por vezes, em função da maior ou menor simpatia momentânea pelas instituições religiosas, fruto, essencialmente, de facções políticas e ideológicas, foram surgindo tentativas de devassa desses espaços misteriosos. São conhecidas as "histórias secretas ou escandalosas dos conventos" que proliferaram em Portugal, sobretudo durante o século XIX, com focos ainda activos na primeira república, reacendidos já no regime democrático por uma determinada esquerda panfletária, que chegou a contaminar uma pseudo-anarquia humoristica que inventava slogans como "nem mais uma freira para o céu".

A par deste interesse, menos inocente do que possa parecer, instalou-se ao longo dos séculos outro, especificamente pela figura da freira, mais privado e muitíssimo menos ingénuo, de cariz fetichista, mas que ainda assim floresceu na arte do século $X X$, o cinema. Basta recordar filmes como Viridiana, de Buñuel, ou Hábitos negros, de Pedro Almodóvar. Hoje o fetiche é oferecido em milhares de páginas de erotismo e pornografia da Internet. Na cultura popular abundam as anedotas picantes ou mesmo obscenas que têm como protagonistas as freiras.

Os séculos XVII e XVIII não escaparam à tentação da devassa. É medianamente conhecida a chamada literatura freirática, não a produção literária de monjas, mas aquela que tem por tema as supostas vidas paralelas de freiras e seus admiradores. É na sua maioria constituida por poesia curta de pendor satírico, como sonetos, décimas, quintilhas, ou outro género breve ${ }^{1}$. Na prosa, há algumas epistolas e escritos de cariz panfletário. Que eu soubesse, o teatro encontra-se, ou encontrava-se, isento destas manifestações jocosas. Mas existiu.

0 género parece ter florescido em Portugal mais do que em qualquer parte da Península Ibérica, se bem que o tipo freirático não seja desconhecido em Espanha, onde a denominação menos pejorativa galán de monjas pode seguramente aplicar-se àquele tipo (Gómez 1990: 81-91). Tanto quanto sei, a figura não se instalou no teatro espanhol. Recentemente tive a oportunidade de trabalhar com Abraham Madroñal, um dos maiores especialistas em entremezes espanhóis do século de ouro, que se admirou de que em Portugal se tivesse desenvolvido este tema, ausente do género espanhol.

Como exemplo do pendor português para a inclusão do universo monástico na sátira entremezil, apresento 0 caso, raro, de adaptação de uma historieta, certamente da cultura popular, nos dois paises. Em Espanha foi dramatizada no entremez La campanilla, atribuido a Agostín Moreto, um dos nomes maiores da comédia seiscentista. Em Portugal acha-se conservada numa colectânea manuscrita de entremezes de princípios do século XVIII com o título A campainha encantada.

Um casal vê-se na posse de uma campainha mágica que tem a propriedade de imobilizar quem a ouve assim que toca, à excepção dos seus donos. Estes decidem divertir-se fazendo-a soar junto de quem for aparecendo. A primeira vítima é um galã que se prepara para estrear um fato novo.
Entre tinieblas (Negros hábitos), realização de Pedro Almodóvar, 1983 (no fotograma, Chus Lampreave e Julieta Serrano).

${ }^{1}$ Veja-se, por exemplo, Sena-Lino (2012) e Hansen (2003), ou as páginas dedicadas ao burlesco e à sátira por Rodrigues (1983)

José Camões é doutorado em Estudos de Teatro pela Faculdade de Letras da Universidade de Lisboa, integra como

investigador o Centro de Estudos de Teatro da FLUL, dirigindo cientificamente vários projectos: Teatro de Autores Portugueses do Século XVI; HTP online: Documentos para a História do Teatro em Portugal; Teatro de

Autores Portugueses do Século XVII: uma

biblioteca digital. Entre as várias publicações que editou e prefaciou destacam-se volumes saídos com a chancela da Imprensa NacionalCasa da Moeda, como os 3 volumes do Teatro português do século XV e outros monográficos de autor (Gil Vicente, Afonso Álvares, António Prestes, Simão

Machado, Anrique Aires Vitória). 
Folha de rosto do

Entremez das freiras,

Biblioteca da Ajuda, Cod.

Ms 50-I-35, f. 22.

Lisboa, janela gradeada, fot. António Henriques.

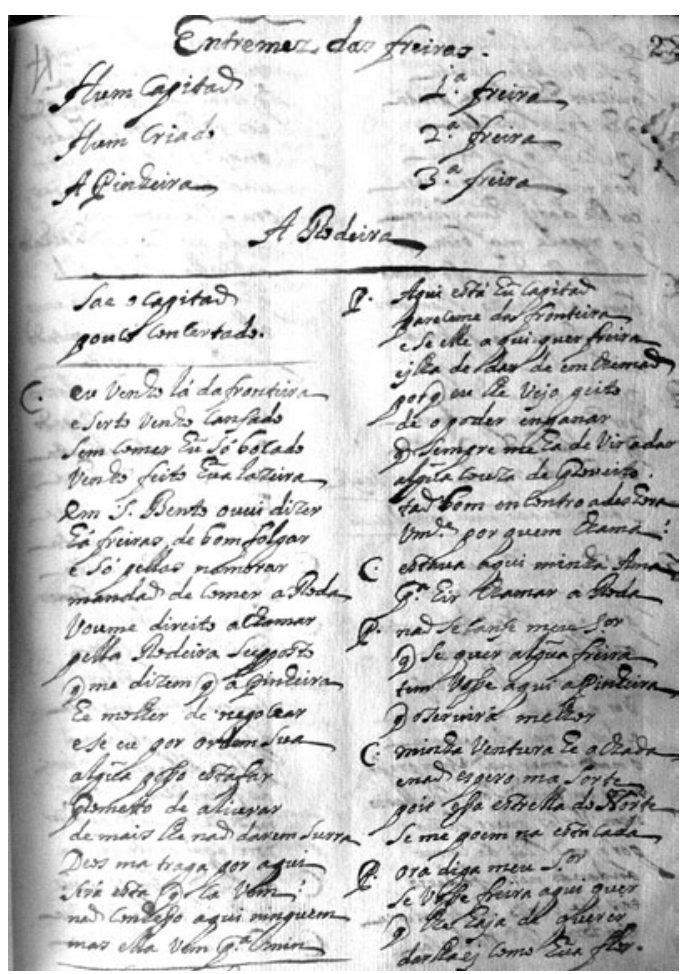

Texto espanhol (Moreto 1691: 21)

Sale don Braulio en jubón y un sastre poniéndole la ropilla u ongarina

Escamilla: Alerta,

porque vistiéndose sale

de nuevo, porque le espera

la procesión de esta tarde.

Don Braulio: El calzón zurdo me aprieta más que el derecho, asi cosa de dos puntadas y media.

Sastre: El tafetán da de sí; si no, aquí está la tijera.

Don Braulio: ¿Y he de pasar yo esta arruga junto al muslo?

Escamilla: Buena flema!

Don Braulio: ¿Cómo ha de quedar airosa la cinta de esta jareta?

Texto português (FLUC CF D- 6-22, f. 297v)

Escondem-se e sai o 1. ${ }^{\circ}$ Galã em véstia e o Alfaiate com tisoura grande e a casaca nas mãos.

Galã 1. Isto é para fazer, diga mestre? Aí há caso como este? Quer você que apareça à vista de ũa abadessa dessa sorte?

Alfaiate Tão mau está este corte que não possa aparecer?

Galã 1. Dê-me você a conhecer que cousa é vestir ao justo e mais à vista de freiras que no que tem de matreiras fazem perder o mais pulcro.

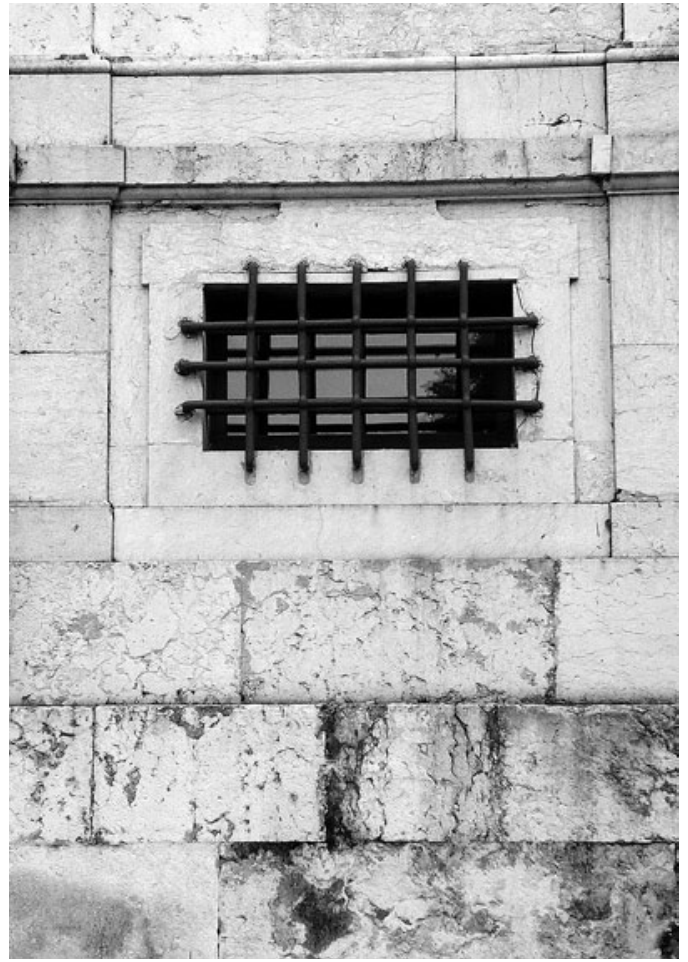

0 projecto Teatro de Autores Portugueses do Século XVII: uma biblioteca digital (PTDC/CLE-LLI/122193/2010, financiado pela Fundação para a Ciência e a Tecnologia), que actualmente dirijo, permitiu encontrar, na sua primeira etapa de pesquisa, nos acervos de várias Bibliotecas e Arquivos, volumes inéditos com entremezes, um género de teatro em Portugal pouco associado ao século XVII, como, aliás, qualquer outro. Encontrou-se na Biblioteca da Ajuda (BA), um volume que o rei D. Carlos ofereceu ao pai, D. Luis, com a seguinte nota manuscrita: "Carlos de Bragança, 20 de Novembro de 1882: Livro de autos e de entremezes dos princípios de 1500; veio de Alcobaça, onde pertencia a um padre que ai morreu". A datação é incorrecta, pois os textos são seiscentistas, mas a proveniência é bem capaz de ser aquela. Dos seus 21 entremezes, 6 são de matéria freirática:

Entremez verdadeiro (ff. 5-12): Frei Folgazão das Chagas; Um Alcaide; Maria Benta, criada; Sousa, criada; Branca das Luzes, freira.

Entremez dos frades (ff. 13-20): Um frade bento; Um frade trino; Um frade jerónimo; Um frade franciscano; Um clérigo; Ũa freira.

Entremez das freiras (ff. 22-26): Um capitão; Um criado; A Pinheira; $1^{\text {a }}$ freira; $2^{\text {a }}$ freira; $3^{\text {a }}$ freira; A rodeira.

Entremez do noivo (ff. 26-30v): Escudeiro; Cura; Noivo; Vilão; Companheiro; Inês, freira; Isabel, freira; Rodeira; Maria, criada; Duas viloas.

Entremez de seis figuras sobre os amantes nas grades das freiras (ff. 95-96v): Pedro Fernandes Monteiro; Dois juizes; Duas freiras; Uma moça.

Entremez de sete figuras (ff. 101-105v): D. Brás; Um moço; Um frade; Um negro; Ũa rodeira; Ũa freira; Ũa moça.

De produção conventual, são também dois volumes de entremezes que se encontram no Arquivo Nacional da Torre do Tombo (ANTT), provenientes da livraria do convento 
de S. Bento ou São João Evangelista de Xabregas, que contêm entremezes freiráticos. No primeiro (Manuscrito da Livraria 109) surgem dois:

Entremez dos frades (ff. 71-80v), numa versão ligeiramente diferente da contida no volume da Biblioteca da Ajuda o que atesta a circulação dos textos.

Entremez do estudante freirático (ff. 125-130): Estudante; Criado; Freira; Criada.

Num segundo volume da mesma livraria (Manuscrito da Livraria 211) encontra-se:

Entremez da freira mouca (ff. 170v-178v): Freira 1a; Uma criada; Freira 2a, mouca; Um frade; Um criado; 0 meirinho.

Por fim, num códice que pertenceu a Carolina Michäelis de Vasconcelos, depositado na Biblioteca da Faculdade de Letras da Universidade de Coimbra (CF D- 6 -22), achamse copiados:

Entremez de Ana Gil (ff. 103-106v): Figuras: Ũa Freira; Sua Criada; Um Estudante; Ana Gil, velha.

Entremez da freira (ff. 212v-216): Figuras: Estudante; Moço Freira; Criada.

Entremez do freirático (ff. 216v-219v): Figuras: Amo; Moço; Escrivão; Meirinho; [Freira]

Neste caso são cópias efectuadas no início do século XVIII, sendo necessário determinar as datas das composições.

Já no século XVIII a tradição parece atenuar-se um pouco, ou estarão ainda por encontrar os entremezes que encenaram as comunicações freiráticas ${ }^{2}$. Mas o certo, e dou apenas um exemplo, é que pelo menos o teatro contaminou outros modos discursivos de tema freirático: Diálogo burlesco intitulado freirática tramóia revelada (BGUC, Ms 582). 0 título convoca a maquinaria cénica como metáfora de truque. A disposição do texto segue a mancha teatral, mas a natureza do discurso é denunciada pela indicação tipográfica humorística: "Com todas as licenças na oficina de dom Desenganado, à custa da experiência, por dom Gostinho de Humor. Vende-se em casa do Passatempo pelo preço de dous vinténs de desejos a quem quer que o quiser ter" (234).

Contam-se, portanto, doze textos inéditos que a seu tempo serão publicados, integrados no projecto acima referido. Mais do que qualquer valor estético que se lhes possa reconhecer, importa convocá-los enquanto prática teatral corrente no Portugal de Seiscentos que deu corpo e voz a uma temática que preenchia o universo satírico da veia artística do génio nacional. Recordo que a chamada literatura freirática não saiu apenas de alguns desconhecidos autores que permaneceram anónimos, mas também dos chamados grandes vultos das letras. A transposição para o teatro, sobretudo nos termos em que é feita, revela, no entanto, um gosto um pouco duvidoso. Neste conjunto de doze entremezes, o tema genérico é o de homens enleados nos amores, proibidos, por freiras. Convenciona-se uma tipologia que se pode resumir, para além da freira, no universo das personagens femininas, a:

1 - a criada, confidente de sua senhora, tipo teatral que no século XVII se deixa contaminar pelas características do antigo moço de escudeiro, com queixas de fome e comentário sarcástico da patroa;

2 - a alcoviteira, normalmente manifestando animosidade para com as criadas, quer seja por rivalidade na obtenção de prémios da senhora freira, quer seja pela extrema fidelidade da criada que desconfia das intenções da mensageira;

3 - a rodeira, uma última personagem feminina que não encontro noutros textos que não sejam subsidiários de trama freirática, com uma função exclusivamente pragmática de verosimilhança. Num teatro "realistico», ou seja, que tenta reproduzir com fidelidade o mundo que se quer reconhecido, a rodeira é inevitável; mas a figura não está totalmente tipificada, oscilando entre o cumprimento puro e simples da sua função de porteira até aos extremos opostos de cumplicidade e desaprovação.

Relativamente às personagens masculinas temos:

1 - os freiráticos (estudante, poeta, capitão, fidalgo e, muito frequentemente, frade ou clérigo, para além de algumas figuras da autoridade que se deixam seduzir);

2 - os respectivos criados, com as características que a tradição teatral fixou de faminto ou guloso e de contraponto gracioso:

3 - os agentes da autoridade (corregedor, juiz, alcaide, meirinho, beleguim, escrivão) que se movem em dois pólos: antes e depois da sedução. Normalmente deixamse prender nas malhas da sedução freirática e entremez em que figurem é quase certo que receberão tareia.

É assim no Entremez verdadeiro, em que Branca das Luzes é desejada por dois pretendentes, um frade e um alcaide. Indecisa, Branca comenta com a criada as vantagens de um e outro: o frade é primoroso no discurso e 0 alcaide tem a bolsa recheada. No entanto, estes predicados parecem não ser suficientes e a freira predispõe-se a ser namorada de quem a requestar. A criada aconselha-a a ficar-se pelos dois. À freira fora-Ihe concedida uma grade que quer repartir pelos dois amantes: um até às três da tarde e outro depois dessa hora, mas a criada mensageira engana-se e convoca ambos para a mesma hora. 0 encontro entre rivais é inevitável e o entremez acaba com o frade a desancar o agente da autoridade.

0 mais emblemático talvez seja o entremez Os amantes nas grades das freiras. A acção tem lugar no
${ }^{2}$ Conheço apenas três titulos: Novo entremez do poeta freirático (manuscrito), suprimido em 1770; Grade da freira (manuscrito); Casado viúva e freira, of. patriarcal de Francisco Luis Ameno, 1755. 


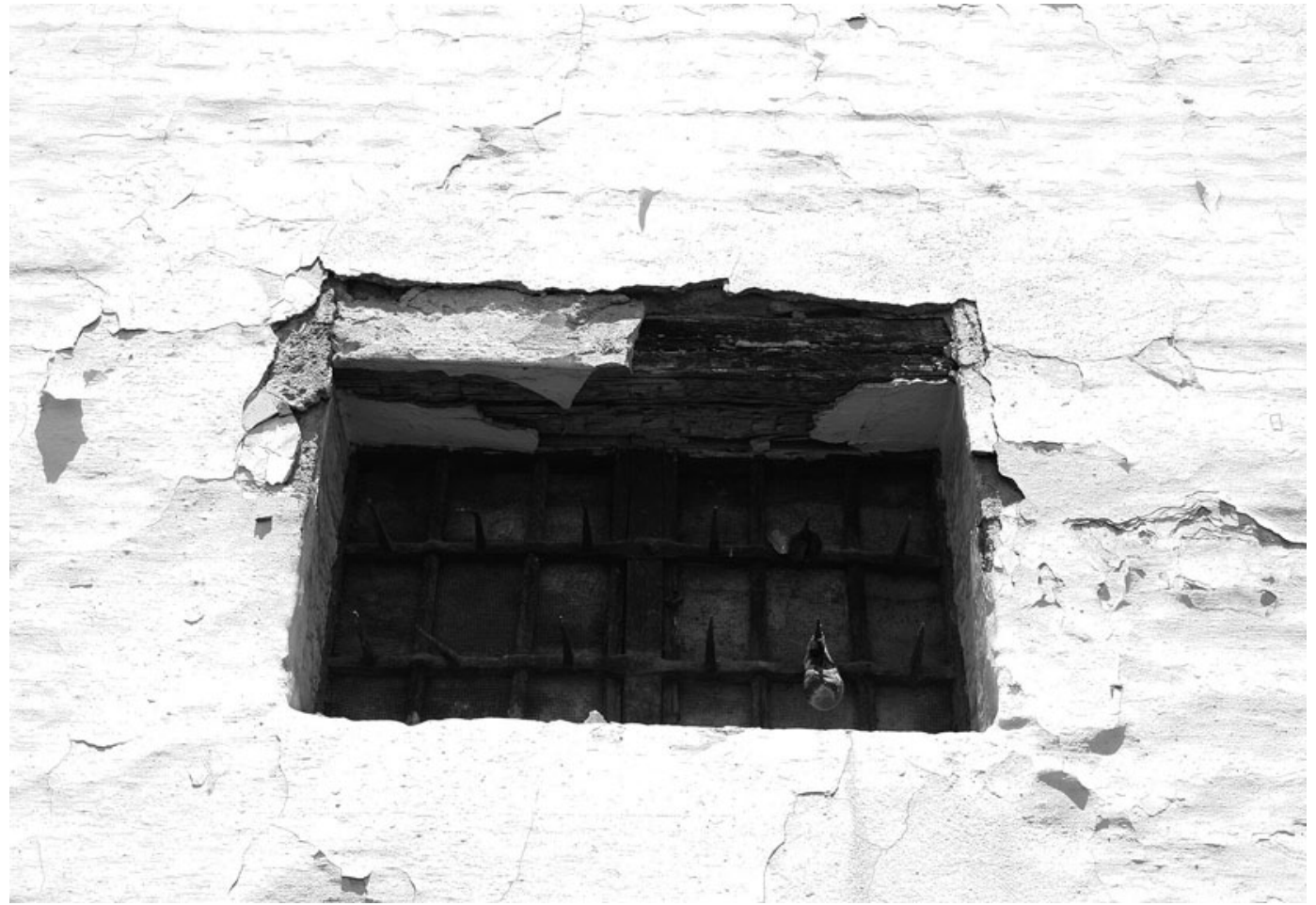

convento de Via Longa após a emissão de um alvará ou qualquer outro diploma que proibe o convivio entre freiras e amorosos. 0 corregedor Pero Fernandes incumbe dois juizes de fazerem sindicância a um mosteiro, determinado a acompanhá-los. Seguidamente, entram em cena duas freiras queixando-se da perspectiva de verem reprimidos os seus encontros, sobretudo por aquele corregedor famoso pela sua intransigência e rigor. Uma delas decide que a sua única esperança é tentar seduzi-lo. Assim que Pero Fernandes tira os óculos para melhor ver as mulheres por quem os freiráticos se perdem fica ele perdido de amores pela freira que o recebe. Chegam os dois juizes do crime que o repreendem e agridem pelo seu inesperado e ilicito comportamento. 0 magistrado acaba por confessar merecer o castigo, não pelo que faz agora mas pelo tempo que demorou a fazê-lo e em que não namorou freiras.

Como se pode observar, há também mulheres encerradas e, teoricamente, inacessiveis, que não desprezam os cortejos dos pretendentes, antes os desejam e, frequentemente, procuram e fomentam. É talvez um ponto de divergência que o teatro apresenta em relação à demais literatura freirática que centra o interesse na figura do freirático. Se bem que aqui se encontrem ainda casos em que os verdadeiros protagonistas são os pretendentes, a verdade é que nalguns entremezes a freira assume uma relevância que ultrapassa a de mero objecto de desejo. De facto, e de acordo com a convenção do género seiscentista o desfecho aponta para a punição, normalmente aplicada através de pancadaria, sendo frequente que a rubrica fina dos entremezes seja "recolhem-se às pancadas"; porém, nestes casos, estando fisicamente impossibilitadas de receber esse tipo de agressão, o castigo surge na forma de humilhação.

Assim acontece no Entremez dos frades, onde um clérigo e quatro frades (um bento, um trino, um franciscano e um jerónimo) disputam o amor de uma noviça junto do ralo de um convento. 0 impasse que se gera só pode ser resolvido pela exibição de habilidades que incluem o galanteio - cada um por sua vez lhe endereça palavras amorosas - e o passear - cada um por sua vez desfila com garbo ridículo - (a rubrica diz: "a seu modo com acções e meneios divertidos" (f. 17v). A freira confessase indecisa mas com coração suficiente para albergar o afecto de todos eles. Contudo, tendo de haver escolha, propõe que se faça pelo canto e, assim, cada um lhe entoa uma canção. A prova é inconclusiva e propõe-se que seja a dança o desafio definitivo. Acabam por engalfinhar-se os frades e fugirem às pancadas, deixando à freira a missão de anunciar a moral da história:

Freira Todos me deixaram, indo-se um e um quem quer a todos, fica sem nenhum. (BA, f. 20)

De forma mais cáustica, o castigo humilhante é aplicado por um criado no Entremez da freira. Um estudante namorado de uma freira confessa ao seu moço o temor de não ser correspondido. 0 criado, disposto a provar ao seu Amo que as freiras não se deixam namorar a não ser na expectativa de algum lucro pecuniário, decide fazerse passar por fidalgo rico junto da pretendida do seu patrão. Depois de convencê-la, e à criada, de que tem mundos e fundos abandona o local, não sem antes Ihes indicar o mealheiro de onde poderão tirar o dinheiro que Ihes prometera: "Levanta a perna, mostra o rabo e foge, deixando-as a olhar pasmadas e leva-Ihe doces e tudo comido e nos bolsos". Todavia, nem sempre a freira é vítima de ultraje; por vezes é ela quem o inflige.

No Entremez das freiras, um capitão, estacionado na fronteira, vai ao Porto para satisfazer a sua necessidade freirática. 0 galanteio começa por uma troca de presentes: um prato de doce de ovos por parte da freira e uma peça inteira de tecido por parte do capitão, que, sem ter dinheiro incitado pela alcoviteira, a manda pedir a um alfaiate, 


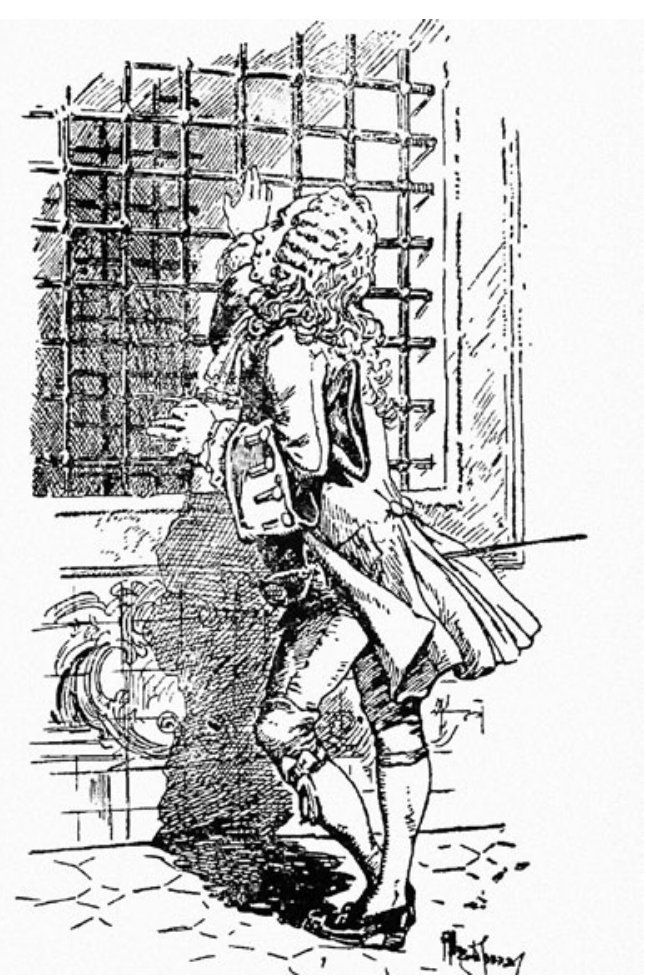

apenas para a freira a apreciar e devolvê-la, se for do seu agrado, para mandá-la cortar para um vestido. Uma vez na posse da peça inteira a ganância da freira faz com que não a devolva.

0 carácter pouco virtuoso de freira oferecida é acentuado pelo registo linguístico que utiliza, exprimindose, na maior parte dos entremezes, com uma rudeza muito pouco conforme ao seu estado e condição. A par da linguagem dos moços e moças, ou de algum frade mais colérico, o registo escatológico contamina a verve inusitada destas personagens, fazendo-se acompanhar, aliás, de gestos pouco próprios das servas de Deus. Em mais do que um entremez se assiste a uma freira a escarrar, não por necessidade de expulsão de secreções mas como mostra de desprezo, num gesto bem pouco feminino ou sedutor.

De todas estas peças a que mais me surpreendeu foi certamente o Entremez da freira mouca. É de uma crueza pouco comum, mesmo tendo em conta o mundo desconchavado em que as personagens se movem. 0 início é sintomático: uma freira insulta a criada ("donde estás, porca, vil, cores de orina? / Oh, cachorra, velhaca, oh, porcalhona" (f. 172), ameaçando-a de bofetadas. A moça esclarecera já o público que a ira da patroa se justifica por precisar de, cito, "chuchar vinténs" (f. 171) ao frade que a namora. Com a chegada do frade e do seu moço à grade começa o galanteio, num tom no mínimo grosseiro:

Pois nesta soledade em que me vejo

Frade: não há carraça, pulga ou percevejo que me não vá ao couro com comichões estouro. Vejo-me exasperado porque depois de estar mui bem coçado sobe-me tal calor ao valdevinos que me vejo sem tinos. (f. 173v-174)
Rapidamente o encontro transforma-se em palco de exibição poética com a glosa que o frade faz aos motes lançados pela freira. 0 tom não destoa da conversa anterior: o primeiro mote que a monja lança é "Todo o Cupido anda nu" (f. 174), seguindo-se uma espécie de reiteração metafórica do discurso amoroso desregrado pelas referências obscenas ao corpo, quer do freirático quer da freira, actos e imprecações de ordem escatológica e outros lugares comuns da luxúria. Tão vulgar é o registo deste diálogo que a glosa do segundo mote chega até a merecer censura por parte da freira:

\section{Essa glosa, meu padre Frei Cigarro, \\ não é de frade de honra, é de masmorra, \\ não merece o decoro de ũa freira \\ ser ultrajado com tão grande asneira. \\ (ff. 175v-174v)}

Os papéis invertem-se, chegando a vez de a freira glosar motes lançados pelo frade (é impossivel não vir à memória as freiras poetas). A devota aproveita para revelar nos versos que faz o desprezo que realmente sente pelo velho frade, que lhe vai retribuir na mesma moeda, debitando uma série de insultos. Vão-se as mulheres e o frade decide partir, mas é interpelado pelo Meirinho que o vem prender. A fúria do frade não se faz esperar: "Oh esbirro de merda, arrede a mão!" (f. 178), terminando por agredir a autoridade. A freira mouca que dá título ao entremez tem uma pequena intervenção cómica de pouca monta.

Mas a imagem da freira nestes entremezes não se resume à descrição que dela se faz num famoso soneto, atribuido quer a António Barbosa Bacelar, quer a Tomás de Noronha ${ }^{3}$ :

\section{A Freira é sanguessuga chupadora, vário camaleão na cor incerto, que toma a cor da cor que está mais perto; só da cor da vergonha não cora. \\ Igual ave em gaiola enganadora, que as néscias aves traz no laço incerto, pescadora sagaz que dá, aberto, o anzol com a minhoca enganadora:}

comisero amante, aranha triste, que o laço em que se enforca urdir pretende, tântalo que não bebe e na água assiste:

sirgo que a sepultura a si fabrica, abelha que o ferrão pregar intende, morre só por picar, morre se pica. (Bacelar 1999: 135-136)

Para além da falsidade do discurso sedutor, diga-se em abono do carácter monacal que encontrei um entremez em que me parece haver sinceridade no amor, sendo o único, aliás, em que há contacto físico entre a freira e 0
"O freirático", ilust. de Alberto Sousa, in Júlio Dantas, 0 amor em Portugal no século XVIII 1916, p. 75.
${ }^{3} 0$ soneto aparece atribuido a António Barbosa Bacelar no f. $86 \mathrm{v}$ do Ms 6269 da Biblioteca Nacional de Portugal, e a Tomás de Noronha no f. 76 do Ms 49-III-52, da Bilbioteca da Ajuda. 
"A grade", ilust. de Alberto Sousa, in Júlio Dantas, 0 amor em Portugal no século XVIII, 1916, p. 96.

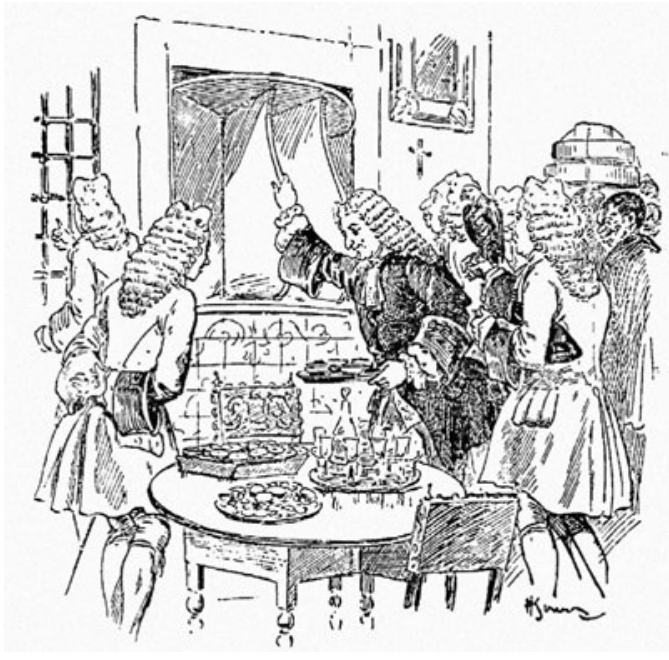

namorado. Trata-se do Entremez de Ana Gil - o nome da alcoviteira. A linguagem da freira aproxima-se muito do discurso amoroso masculino padrão, transformando-se o objecto de desejo em sujeito desejoso.

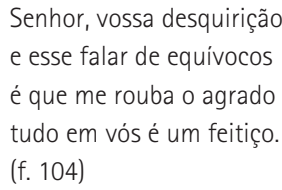

Os efeitos da poesia não se fazem esperar:

São de vosso intendimento
hipérboles conhecidos
mas o ser vossa me dá
valimento tão subido.
(f. 105)

Para além da tipologia das figuras, estes entremezes apontam para um subgénero instalado que se reconhece facilmente no cenário exigido: uma rua, uma portaria de convento com ralo e roda de um lado e do outro, ou, ao fundo, o local da grade. A moda amorosa certamente terá ditado o costume de visitar as grades dos conventos. Os exageros cometidos terão proporcionado o aparecimento de uma série de legislação punitiva desde princípios do século XVII até meados do século XVIII que proíbe a conversação considerada ilícita e se faz sentir também no teatro ao introduzirem-se nos entremezes as figuras da autoridade, como juizes, meirinhos, alcaides, beleguins e escrivães.

0 que se representa é a vox populi que circulava pela literatura satírica e que, em 1915, Júlio Dantas descreveu com alguma acuidade nas secções dedicadas à grade e ao freirático em 0 amor em Portugal no século XVIII. Não sei se, depois de ler estes entremezes, concordo totalmente com a sua tese de que o amor freirático era a quintaessência do platonismo português. Parece-me mais a representação da transgressão de normas ético-políticas, numa sátira que só aparentemente mimetiza os preceitos do amor cortesão, deixando entrever na troca de correspondência e de alimentos entre o convento e o exterior marcas da volúpia do proibido.

Mas houve, e há certamente, freiras simpáticas, até de algum modo ligadas ao teatro. Apreciadora de entremezes, soror Violante do Céu dedica uma décima a Manoel Coelho Rebelo, autor da Musa entretenida de vários entremezes, que publica em 1658, em plena febre freirática:

Con tal gracia entretenéis a quien burlando agradáis que cuanto más os burláis más aplausos merecéis. Tan singular os hacéis que es fuerza que al mundo asombre pues costando tanto a un hombre ir su nombre eternizando vos solamente burlando eternizáis vuestro nombre. (Céu 1658)

\section{Referências bibliográficas}

BACELAR, António Barbosa (1999), "Definição de uma freira", in Antologia da poesia portuguesa erótica e satírica (selecção, prefácio e notas de Natália Correia), Lisboa, Antígona, 3. ed.

CÉU, Soror Violante do (1658), "Décima" in Manuel Coelho Rebelo, Musa entretenida de vários entremeses, Coimbra, Manuel Dias, s.f.

DANTAS, Júlio (1916), 0 amor em Portugal no século XVIII, Porto, Livraria Chardron de Lello e Irmão.

GÓMEZ, Jesús (1990), "La tradición literaria del galán de monjas", in Edad de Oro, 9, pp. 81-91.

HANSEN, João Adolfo (2003), "Pedra e cal: freiráticos na sátira lusobrasileira do século XVII", in Revista USP, n. ${ }^{\circ}$ 57, março/maio, São Paulo, pp. 68-85

MORETO, Agostin (1691), "Entremés de la campanilla", in Floresta de entremeses, Madrid, Antonio de Zafra, pp. 20-27.

RODRIGUES, Graça Almeida (1983), Literatura e sociedade na obra de Frei Lucas de Santa Catarina (1660-1740), Lisboa, Imprensa Nacional Casa da Moeda.

SENA-LINO, Pedro António Freire Santos (2012), Estratégias por correspondência: Uma leitura da obra de Feliciana de Milão, Tese de Doutoramento no Ramo de Estudos de Literatura e de Cultura Estudos de Literatura e Cultura de Expressão Portuguesa, Universidade de Lisboa, Lisboa, texto inédito.

\section{Fontes manuscritas}

Arquivo Nacional da Torre do Tombo (ANTT) - Manuscrito da Livraria 109,

$$
\text { S.I. s.n. }
$$

Arquivo Nacional da Torre do Tombo (ANTT) - Manuscrito da Livraria 211, S.I. s.n.

Bilbioteca da Ajuda (BA) - Cod. Ms 50-I-35, S.I. s.n.

Biblioteca da Faculdade de Letras da Universidade de Coimbra (FLUC) CF D- 6-22, S.I. s.n.

Biblioteca Geral da Universidade de Coimbra (BGUC), Ms 582, S.I. s.n. 